Revista Brasileira de Agricultura Irrigada v.11, nº.7, p. 1986 - 1997, 2017

ISSN 1982-7679 (On-line)

Fortaleza, CE, INOVAGRI - http://www.inovagri.org.br

DOI: $10.7127 /$ rbai.v11n700666

Protocolo 666.17 - 22/04/2017 Aprovado em 22/08/2017

\title{
WATER SALINITY AND BOVINE BIOFERTILIZER IN THE PRODUCTION OF EGGPLANT SEEDLINGS
}

Mário Leno Martins Véras ${ }^{1}$, José Sebastião de Melo Filho² ${ }^{2}$ Lunara de Sousa Alves ${ }^{3}$, Toshik Iarley da Silva ${ }^{4}$, Anderson Carlos de Melo Gonçalves ${ }^{5}$, Thiago Jardelino Dias ${ }^{6}$

\begin{abstract}
The use of saline water in agriculture is an alternative for those producers that do not have water of good quality for irrigation, however, some crops do not tolerate saline stress and as a strategy to mitigate the saline stress effects it has been recommended the use of organic inputs. Based on that, the aim of this study was to evaluate the effect of different electrical conductivities of the irrigation water associated to the application of bovine biofertilizer in the eggplant (Solanum melongena L.) crop. The experiment was carried out in a greenhouse located at the Universidade Estadual da Paraíba, in the municipality of Catolé do Rocha-PB, Brazil. It was used a completely randomized experimental design, with a $4 \times 2$ factorial scheme, with 6 replicates. The treatments consisted of the combination of the electrical conductivity of the irrigation water (ECw): 0.8; 2.4; 4 e $5.6 \mathrm{dS} \mathrm{m}^{-1}$ and the application of bovine biofertilizer (presence and absence). Based on the results of this research, it was possible to conclude that irrigation with saline water from $0.8 \mathrm{dS} \mathrm{m} \mathrm{m}^{-1}$ affects negatively the growth and the dry matter production of eggplants. The application of bovine biofertilizer provides positive results in eggplant plants, attenuating the negative effects of saline stress.
\end{abstract}

Keywords: saline water, organic inputs, Solanum melongena L.

\section{SALINIDADE HÍDRICA E BIOFERTILIZANTE BOVINO NA PRODUÇÃO DE MUDAS DE BERINJELA}

\footnotetext{
RESUMO

O uso de águas salinas na agricultura é uma alternativa para produtores que não têm disponibilidade de água de boa qualidade para irrigação, contudo, algumas culturas não toleram o estresse salino e como estratégia de atenuar seus efeitos tem-se recomendado o uso de

${ }^{1}$ Doutorando em Fitotecnia, UFV, Viçosa-MG, e-mail: mario.deus1992@bol.com.br

2 Doutorando em Agronomia, UFPB, e-mail: sebastiaouepb@yahoo.com.br

${ }^{3}$ Mestranda em Sistemas Agroindustriais, UFPB, Bananeiras-PB, e-mail: lunara-alvesuepb@hotmail.com

${ }^{4}$ Mestrando em Agronomia, UFPB, Areia-PB, e-mail: iarley.toshik@gmail.com

${ }^{5}$ Mestrando em Agronomia, UFPB, Areia-PB, e-mail: anderson.agroufpb@yahoo.com

${ }^{6}$ Doutor em Agronomia, Prof. UFPB, Bananeiras-PB, e-mail: thiagojardelinodias@gmail.com
} 
insumos orgânicos. Neste sentido, objetivou-se avaliar o efeito de diferentes condutividades elétricas da água de irrigação associado à aplicação de biofertilizante bovino na cultura da berinjela (Solanum melongena L.). O experimento foi conduzido em casa de vegetação localizada na Universidade Estadual da Paraíba no município de Catolé do Rocha-PB, Brasil. Adotou-se o delineamento experimental inteiramente casualizado, com esquema fatorial $4 \times 2$, com 6 repetições. Os tratamentos constaram da combinação da condutividade elétrica da água de irrigação (CEa): 0,8; 2,4; 4 e 5,6 dS m m $^{-1}$ e a aplicação de biofertilizante bovino (ausência e presença). Com base nos resultados desta pesquisa foi possível concluir que a irrigação com águas salinas a partir de $0,8 \mathrm{dS} \mathrm{m}^{-1}$ afeta negativamente o crescimento e a produção de matéria seca de berinjela. A aplicação de biofertilizante bovino proporciona resultados positivos nas plantas de berinjela, atenuando os efeitos deletérios do estresse salino.

Palavras-chave: água salina, insumo orgânico, Solanum melongena L.

\section{INTRODUCTION}

The eggplant (Solanum melongena L.) belongs to the Solanaceae family, and is worldwide consumed. The cultivation of this vegetable has been carried out in protected environment, where it is possible a greater control, consequently, allowing higher yields as well as continuous supply in periods when supplies in the market are low, besides the aggregation value to the product (COSTA et al., 2011). This crop is a shrub, with a semiligneous stem, reaching a height of more than one meter (SILVA et al., 2013).

The low availability of water and the quality of the irrigation water that will be used in the irrigation of the eggplant are extremely important, especially when it regards salt concentrations (OLIVEIRA et al., 2011). The eggplant is moderately sensitive to salinity, tolerating up to the limit of $1.5 \mathrm{dS} \mathrm{m}^{-1}$, reducing its yield in $4.4 \%$ at each increased unit of salinity (ÜNLÜKARA et al., 2010).

Studies of the effects of salinity on irrigation water on the cultivation of eggplant, from seedlings to its production, have increased, as reported by Bosco et al. (2015; 2009), Moura and Carvalho (2014), Silva et al. (2013) Oliveira et al. (2011) and Ünlükara et al. (2010), they reported a reduction in the growth of this vegetable when submitted to different salinity concentrations of the irrigation water.

Due to the negative effects that the use of saline water in agriculture causes in plants, such as reduction in growth and yield, the use of organic inputs has been recommended in order to reduce the action of the salts, mainly due to its rich composition in humic substances, which act increasing the osmotic regulation between root and soil solution, besides reducing the intensity of the toxic effects of the salts in the plant growth (AYDIN et al., 2012).

The use of organic fertilizers, such as the bovine biofertilizer, reduces the costs with synthetic fertilizers, since the production of the organic inputs are easy to acquire and it supplies most of the nutrients that the plants need. Another advantage with its use is that improper fertilization with mineral fertilizers can cause damage to the environment, causing the salinization of agricultural areas.

The aim of this study was to evaluate the effect of different electrical conductivities on irrigation water associated to the application of bovine biofertilizer in the production of eggplant (Solanum melongena L.) seedlings.

\section{MATERIAL AND METHODS}

This study was carried out from September to November of 2015 in a greenhouse at no Centro de Ciências Humanas e Agrárias Departamento de Agrárias e Exatas da Universidade Estadual da Paraíba in the municipality of Catolé do Rocha-PB, Brazil (6 - 20 '38 "S; 37 ○ 44'48" W) 275 meters of elevation. The climate of the municipality, according to the Koppen classification, is of the type BSW ', which is warm and dry, steppe type, with average monthly temperature above $18^{\circ} \mathrm{C}$, throughout the year. 
The experimental design used was a completely randomized, with a $4 \times 2$ factorial scheme, with 6 replicates. The treatments consisted of the combination of the electrical conductivity factor of irrigation water (ECw) of $0.8 ; 2.4 ; 4$ e $5.6 \mathrm{dS} \mathrm{m}^{-1}$, concomitantly associated with the application of bovine biofertilizer (presence and absence).

The standard water used in the irrigation had a electrical conductivity of $0.8 \mathrm{dS} \mathrm{m} \mathrm{m}^{-1}$, which was analyzed in the Laboratório de Irrigação e Salinidade (LIS) of the Centro de Tecnologia e Recursos Naturais da Universidade Federal de Campina Grande (UFCG). The soil used was classified as a
Flubic Neosol with a sandy loam texture. The samples were collected in the $0-20 \mathrm{~cm}$ depths of the soil in a native area located in the UEPB campus (Table 1 ).

The biofertilizer was obtained by anaerobic fermentation, in a hermetically sealed environment. To release the methane gas at the top of each biodigester an end of a thin hose was coupled and the other end of it was immersed in a vessel with water. Were used 70 $\mathrm{kg}$ of bovine manure from lactating cows and 120 liters of water to prepare the biofertilizer, 5 $\mathrm{kg}$ of sugar and 5 liters of milk were added to accelerate the metabolism of the bacteria (SILVA et al., 2012) (Table 1).

Table 1. Chemical properties of the soil, water and bovine biofertilizer.

\begin{tabular}{|c|c|c|c|}
\hline Characteristics & Soil & Water & $\begin{array}{c}\text { Bovine } \\
\text { biofertilizer }\end{array}$ \\
\hline $\mathrm{pH} \mathrm{CaCl} 2$ & 5,02 & 7,53 & 4,68 \\
\hline$* \mathrm{EC}\left(\mathrm{dS} \mathrm{m}^{-1}\right)$ & 0,60 & 0,80 & 4,70 \\
\hline $\mathrm{Ca}^{+2}$ cmolc dm-3 & 4,63 & 2,30 & 3,75 $\mathrm{cmol}_{\mathrm{c}} \mathrm{L}^{-1}$ \\
\hline $\mathrm{Mg}^{+2}$ cmolc dm-3 & 2,39 & 1,56 & 3,30 $\mathrm{cmol}_{\mathrm{c}} \mathrm{L}^{-1}$ \\
\hline $\mathrm{Na}^{+}$cmolc dm-3 & 0,3 & 4,00 & $1,14 \mathrm{cmol}_{\mathrm{c}} \mathrm{L}^{-1}$ \\
\hline $\mathrm{K}^{+}$cmolc dm-3 & 0,76 & 0,02 & $0,71 \mathrm{cmol}_{\mathrm{c}} \mathrm{L}^{-1}$ \\
\hline $\left.\mathrm{P}(\mathrm{mg} \mathrm{dm})^{3}\right)$ & 0,70 & 0,00 & 14,45 \\
\hline $\mathrm{Al}^{3+}\left(\mathrm{cmol}_{\mathrm{c}} \mathrm{dm}^{-3}\right)$ & 0,00 & 0,00 & 0,00 \\
\hline $\mathrm{H}^{+}+\mathrm{Al}^{3+}\left(\mathrm{cmol}_{\mathrm{c}} \mathrm{dm}^{-3}\right)$ & 1,00 & 0,00 & 1,00 \\
\hline BS & 7,78 & 0,00 & 7,76 \\
\hline $\mathrm{T}$ & 8,08 & 0,00 & 8,90 \\
\hline $\mathrm{OM}\left(\mathrm{g} \mathrm{kg}^{-1}\right)$ & 8,05 & 0,00 & 8,00 \\
\hline Cloride (cmolc dm-3) & 0,00 & 3,90 & 0,00 \\
\hline Carbonate (cmolc dm-3) & 0,00 & 0,57 & 0,00 \\
\hline Bicarbonates (cmolc dm-3) & 0,00 & 3,85 & 0,00 \\
\hline SAR (mmolc l-1)1/2 & 0,00 & 2,88 & 0,00 \\
\hline
\end{tabular}

${ }^{*}=$ Electrical conductivity of the extract of 1:2,5; P, K, Na: Mehlich1 extract; $\mathrm{Al}, \mathrm{Ca}$, Mg: extractor $\mathrm{KCl}$ 1,0 mol L-1 $\mathrm{BS}=$ $\mathrm{Ca}^{+2}+\mathrm{Mg}^{+2}+\mathrm{K}^{+}+\mathrm{Na}^{+} ; \mathrm{H}^{+}+\mathrm{Al}^{3+}$ : Calcium acetate extractor $0,5 \mathrm{~mol} \mathrm{~L}-1, \mathrm{pH}$ 7,0; $\mathrm{CEC}=\mathrm{SB}+\mathrm{H}^{+}+\mathrm{Al}^{+3}$; O. M.: Walkley-Black humid digestion.

After the dilution of the bovine biofertilizer, the treatments were applied 15 days after sowing (DAS), at intervals of 8 days, totalizing 6 applications in a dosage of $5 \%$ of the volume. The salinity treatments were performed 15 days after the emergence. Prior to application, the biofertilizer was subjected to a screen filtration process to reduce the risk of obstruction of the orifice of the watering sieve.

The ECw were obtained by the addition of sodium chloride $(\mathrm{NaCl})$ in the water from the local supply system, according to Rhoades et al. (2000) where the amount of salts (Q) was determined by Equation 1 ': 


$$
Q(m g L)=E C w \times 640
$$

Where: ECw (0.8 dS $\left.\mathrm{m}^{-1}\right)$ represents the desired value of the electrical conductivity of the water.

The sowing was performed in plastic bags of $4 \mathrm{dm}^{3}$ capacity, with dimensions of $20 \times 35$ $\mathrm{cm}$. The experimental units were composed of three plants grown in polyethylene bags with a capacity of $4 \mathrm{dm}^{3}$. Three eggplant seeds were sown for each experimental unit. At 20 days after sowing, the thinning of the seedlings were performed maintaining only the most vigorous seedling.

At the end of the experiment, 90 days after sowing (DAS) the plants were collected for evaluation of the following variables: plant height, stem diameter, leaf number, total leaf area, dry matter of root, stem, leaves and total dry matter.

A measuring tape in $\mathrm{cm}$ was used to measure plant height, from the distance of the base of the plant stem to the apex of the plant (insertion of the youngest leaf completely formed). Measurements of stem diameter (SD) were performed with a digital caliper at $2 \mathrm{~cm}$ above the base of the plant stem. The number of leaves were obtained by counting. The root dry matter, stem dry matter and leaf dry matter were determined after the fresh matter remained in a stove for approximately 48 hours at a temperature of $60{ }^{\circ} \mathrm{C}$ until reach a constant weight, and then weighed on a precision scale (0.0001g). The total dry matter was obtained by summing all the dry parts of the plant (root, stem and leaf).

From the mean values of plant height, stem diameter and leaf area, absolute growth rates (AGR) and relative growth rates (RGR) were calculated according to Benincasa (2003).

$$
\mathrm{AGR}=\frac{(A 2-A 1)}{(\mathrm{t} 2-\mathrm{t} 1)}
$$

Where: AGR - absolute growth rate; A2 - plant growth in the $\mathrm{t} 2$ period; A1 -plant growth in the $\mathrm{t} 1$ period; , $\mathrm{t} 2$ - $\mathrm{t} 1$ - time difference among the samples.

$$
R G R=\frac{(\ln A 2-\ln A 1)}{(t 2-t 1)}
$$

Where: RGR - relative growth rate; A2 - plant growth in the t2 period; A1 - plant growth in the $\mathrm{t} 1$ period; $\mathrm{t} 2$ - $\mathrm{t} 1$ - time difference among the samples; and, ln - natural logarithm.

Data were submitted to analysis of variance by the "F" test and, in case of significance, linear and quadratic polynomial regression analysis were performed using the SISVAR $5.1^{\circledR}$ statistical software (FERREIRA, 2011).

\section{RESULTS AND DISCUSSION}

The electrical conductivity levels in the irrigation water (ECw) influenced statistically all of the analyzed variables, as described in the analysis of variance (Table 1). Regarding the application of bovine biofertilizer, it was observed significant effects for the number of leaves, total leaf area, absolute growth rate of plant height, absolute leaf growth rate, leaf dry matter and total dry matter. For the interaction between ECW $\mathrm{x}$ and bovine biofertilizer levels, it was verified that there was a significant effect for stem diameter, number of leaves, total leaf area, absolute growth rate of stem diameter and dry matter of root, stem , leaves and total dry matter.

Table 1. Analysis of variance for plant height (PH), stem diameter (SD), leaf number (LN), total leaf area (TLA) and root length (RL), absolute and relative growth rate of plant height (AGRph and RGRph), stem diameter (AGRsd and GRGsd) and leaf area (AGRla and RGRla), dry matter of root (DMR), stem (DMS), leaf (DML) and total dry matter (TDM) of eggplant under effect of levels of electrical conductivity in irrigation water $(\mathrm{ECw})$ as a function to the application of bovine biofertilizer (B).

\begin{tabular}{lllllll}
\hline \multirow{2}{*}{ Source of Variation } & DF & \multicolumn{5}{c}{ Middle Square } \\
\cline { 3 - 6 } & & PH & SD & LN & TLA & RL \\
\hline
\end{tabular}




\begin{tabular}{|c|c|c|c|c|c|c|c|}
\hline Condutiv. (ECw) & 3 & $115,89 * *$ & \multicolumn{2}{|c|}{$12,46 * *$} & $39,28 * *$ & $2329,31 * *$ & $66,80 * *$ \\
\hline Biofertilizer (B) & 1 & $35,17^{\mathrm{ns}}$ & \multicolumn{2}{|c|}{$0,07^{\mathrm{ns}}$} & $11,28 *$ & $466,95^{* *}$ & $2,77^{\mathrm{ns}}$ \\
\hline Interation ECw x B & 3 & $5,82^{\mathrm{ns}}$ & \multicolumn{2}{|c|}{$1,37 *$} & $3,61^{*}$ & $294,97 * *$ & $4,11^{\mathrm{ns}}$ \\
\hline Residue & 24 & 5,84 & \multicolumn{2}{|c|}{0,23} & 0,84 & 10,87 & 6,52 \\
\hline \multirow[t]{2}{*}{ CV (\%) } & \multirow[t]{2}{*}{-} & 13,14 & 10,88 & & 13,42 & 4,04 & 13,28 \\
\hline & & AGRph & RGRph & AGRsd & GRGsd & AGRla & RGRla \\
\hline \multicolumn{2}{|l|}{ Condutiv. (ECw) } & $0,0144 * *$ & $0,0007 * *$ & $0,0003 * *$ & $0,0253 * *$ & $0,2534 * *$ & $0,0007 * *$ \\
\hline Biofertilizer (B) & 1 & $0,0050 *$ & $4,5125^{\mathrm{ns}}$ & $0,0153^{\text {ns }}$ & $0,0003^{\text {ns }}$ & $0,0068^{*}$ & $2,0008^{\mathrm{ns}}$ \\
\hline Interation ECw x B & 3 & $0,0004^{\mathrm{ns}}$ & $1,5125^{\mathrm{ns}}$ & $0,1453^{*}$ & $0,0003^{\mathrm{ns}}$ & $0,0079^{\text {ns }}$ & $2,9108^{\mathrm{ns}}$ \\
\hline Residue & 24 & 0,0007 & 1,3812 & 0,0239 & 0,0003 & 0,0010 & 4,7908 \\
\hline \multirow[t]{2}{*}{ CV (\%) } & \multirow[t]{2}{*}{-} & 1,86 & 10,32 & 12,58 & 13,80 & 4,50 & 9,92 \\
\hline & & DMR & \multicolumn{2}{|r|}{ DMS } & DML & \multicolumn{2}{|r|}{ TDM } \\
\hline Condutiv. (ECw) & 3 & $8,11^{* *}$ & \multicolumn{2}{|c|}{$29,20 * *$} & $47,83 * *$ & \multicolumn{2}{|c|}{$218,54^{* *}$} \\
\hline Biofertilizer (B) & 1 & $4,30^{\mathrm{ns}}$ & \multicolumn{2}{|r|}{$2,52^{\mathrm{ns}}$} & $25,56^{* *}$ & \multicolumn{2}{|c|}{$76,01^{* *}$} \\
\hline Interation ECw x B & 3 & $0,97 *$ & \multicolumn{2}{|r|}{$6,30 *$} & $17,49 *$ & \multicolumn{2}{|c|}{$48,09 * *$} \\
\hline Residue & 24 & 0,30 & \multicolumn{2}{|r|}{0,74} & 1,89 & \multicolumn{2}{|r|}{$3,52 * *$} \\
\hline CV (\%) & - & 17,27 & \multicolumn{2}{|r|}{21,68} & 17,68 & \multicolumn{2}{|r|}{12,57} \\
\hline
\end{tabular}

CV: Coefficient of variation; DF: Degrees of freedom; * , **: significant at 5 and $1 \%$, respectively, and ${ }^{\text {ns: }}$ non-significant by the $\mathrm{F}$ test.

The plant height (Figure 1) presented a significant effect when submitted to different ECw, behaving linearly in a decreasing way, with the minimum values obtained in the highest salinity levels with a plant height of $14.37 \mathrm{~cm}$. For the stem diameter (Figure 1), there was a significant effect on the interaction between ECw and the application of bovine biofertilizer, in which plants irrigated with low levels of saline water had a higher growth in stem diameter compared to those irrigated with high levels of saline water, even with the application of bovine biofertilizer.
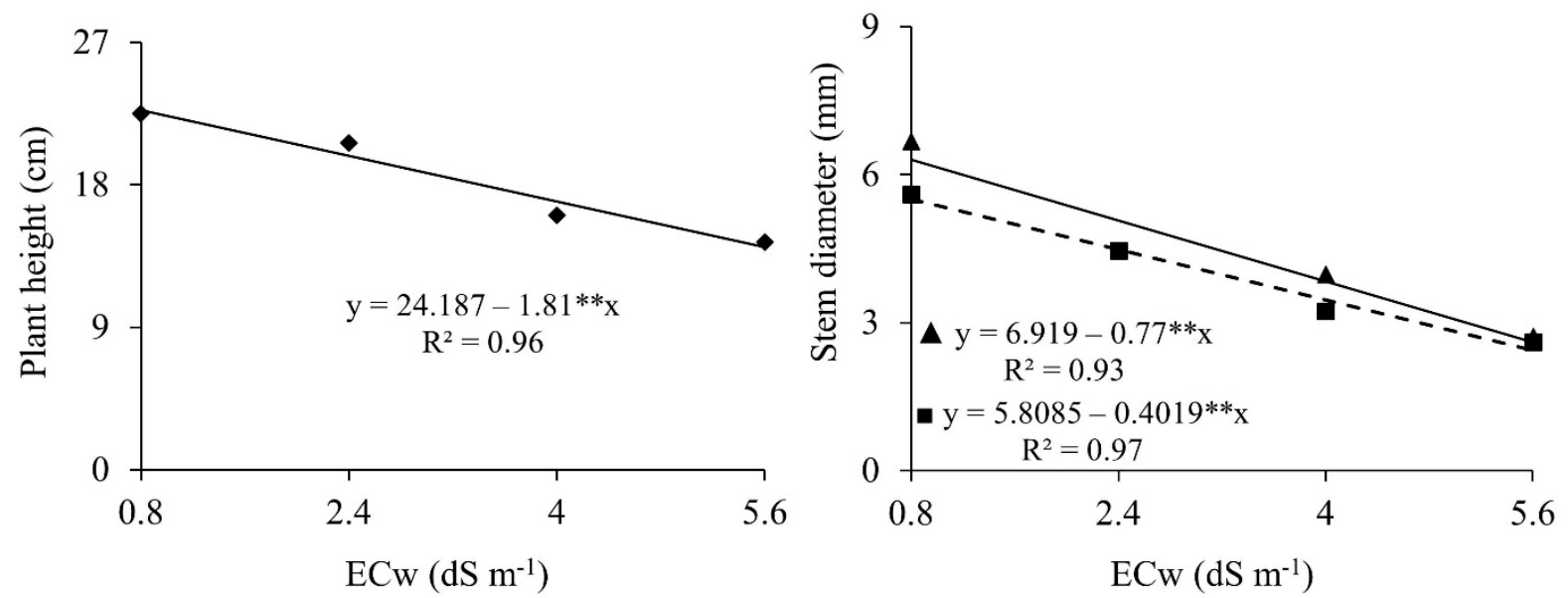

Figure 1. Plant height and stem diameter of eggplants under ECw effect associated with presence $(\boldsymbol{\Delta})$ and absence (s) of bovine biofertilizer.

However, the organic input promoted a larger stem diameter in the eggplant plants. When irrigated with low levels of saline water, the plants had a diameter of $6.67 \mathrm{~mm}$ in the presence of the biofertilizer, while under irrigation with high levels of saline 
water the stem diameter was $2.72 \mathrm{~mm}$ (Figure 1).

These results are in agreement with some found in the literature (MOURA and CARVALHO, 2014; OLIVEIRA et al., 2011; ÜNLÜKARA et al., 2010). Moura and Carvalho (2014) and Oliveira et al. (2011) observed a linear reduction of the diameter of the eggplant stem with an increase in the salinity of the irrigation water.

It is possible to observe a quadratic response for the leaf number (Figure 2) and a decreasing linear response for the total leaf area (Figure 2) in response to the interaction of $\mathrm{ECW}$ with the application of bovine biofertilizer; Where the best results were obtained with the water irrigation with lowest ECw, of $0.8 \mathrm{dS}^{-}$ ${ }^{1}$ corresponding to the maximum value of 11.75 leaves without the application of biofertilizer, while for the total leaf area with the application of biofertilizer, the plants had a total leaf area of $113.4 \mathrm{~cm}^{2}$ in the minimum level of salinity $(0.8$ $\left.\mathrm{dS} \mathrm{m}^{-1}\right)$.
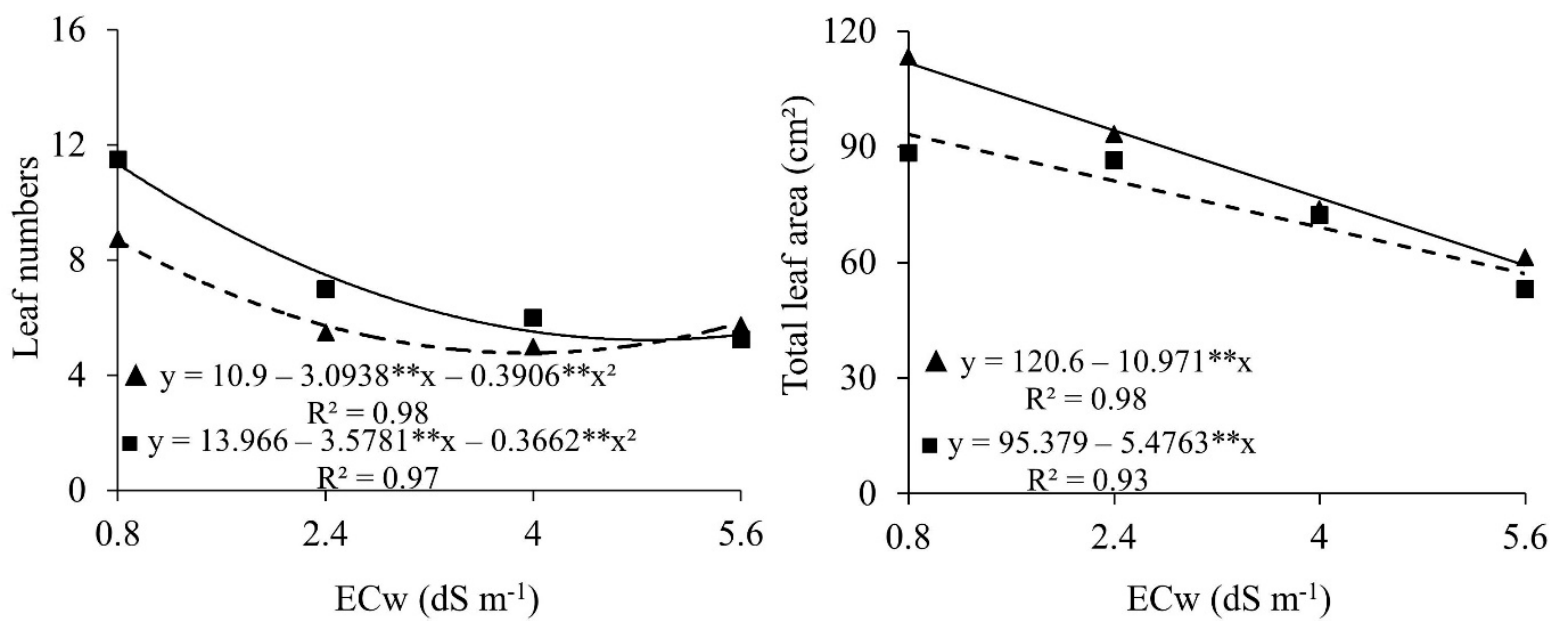

Figure 2. Number of leaves (A) and total leaf area (B) of eggplant plants under ECw effect associated with presence ( $\boldsymbol{\Delta})$ and absence ( $\boldsymbol{\square})$ of bovine biofertilizer.

Oliveira et al. (2011), found that the number of leaves and leaf area of eggplant were significantly affected by the increased salinity of the irrigation water. This is explained by the sensitivity of the leaves, since high concentrations of salts reduce the size and number of leaves, they observed that the leaf area had a significant and positive response between the first two saline levels ( 0.5 and 1.5 $\mathrm{dS} \mathrm{m}^{-1}$ ), thus adjusting to a quadratic regression equation, with the maximum total leaf area estimated to be $2178.9 \mathrm{~cm}^{2}$ for the salinity of $1.2 \mathrm{dS} \mathrm{m}^{-1}$.

Medeiros et al. (2011), studying the application of biofertilizer in cherry tomatoes, found that the plants treated with biofertilizer presented a higher number of leaves and leaf area compared to those without the treatment. Silva et al. (2013) on salinity levels and fertigation management on eggplant characteristics cultivated in protected environment did not find significant results for the number of leaves when the plants were submitted to salinity levels.

The decrease in leaf number and size is a strategy that the plant has in order to support saline stress, since these plant organs are sensitive, thus reduce its size and number in the presence of high concentrations of salts. In addition, the decrease in the emission of new leaves, the decrease in the leaf area occurs due to the acceleration of the senescence of the leaves, possibly causing the plant death (MAHMOUD; MOHAMED, 2008).

The same behavior for the previous mentioned variables can be observed in Figure 3, for the length of the eggplant plant root, where the data adjusted to the decreasing linear model; As the $\mathrm{ECw}$ was increased there was a significant reduction on root length, indicating the lowest values for the highest salinity (5.6 dS m$~^{-1}$ ) with a value of $16.74 \mathrm{~cm}$. 


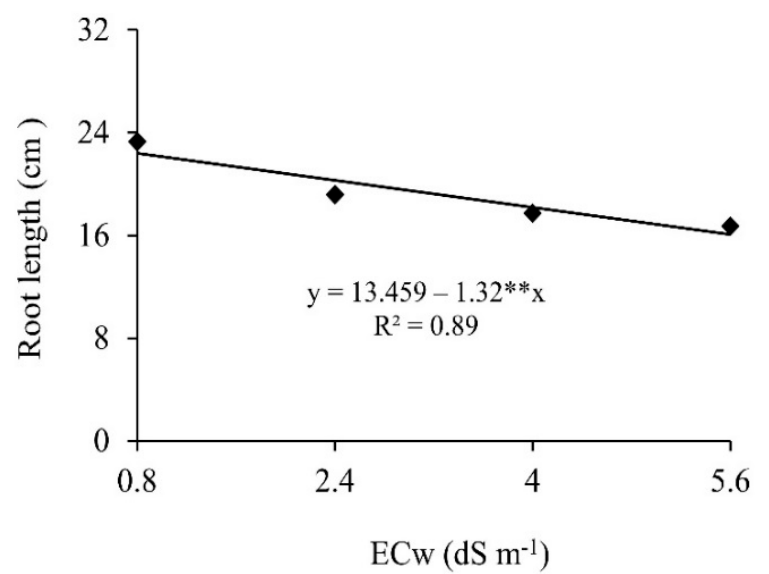

Figure 3. Root length of eggplant plants under the ECw effect.

Campos and Cavalcante (2009) on pepper seedlings production irrigated with saline water and submitted to the application of biofertilizer and Mesquita et al. (2012) in passion fruit seedlings verified that the seedlings treated with biofertilizer and with increasing salinity of water surpassed those that did not have treatment with the input in the soil.

For the absolute growth rate of plant height (AGRpH), it can be observed (Figure 4) that the eggplant plants irrigated with saline water had a reduction as the ECw increased, where the plants irrigated with water of $0.8 \mathrm{dS}$ $\mathrm{m}^{-1}$ presented a growth rate of $0.2 \mathrm{~cm} \mathrm{dia}^{-1}$, while the plants submitted to higher salinity $\left(5.6 \mathrm{dS} \mathrm{m} \mathrm{m}^{-1}\right)$ obtained a growth rate of $0.1 \mathrm{~cm}$ dia- 1 , representing a decrease of $50 \%$ for each increase unit of ECw.

The Figure 4 shows the effect of the application of bovine biofertilizer on the absolute growth rate of plant height, in which it is verified that its application provided superior results, obtaining value of $0.15 \mathrm{~cm} \mathrm{day}^{-1}$, whereas without application of biofertilizer the results were less than $0.14 \mathrm{~cm}_{\text {day }^{-1}}$.
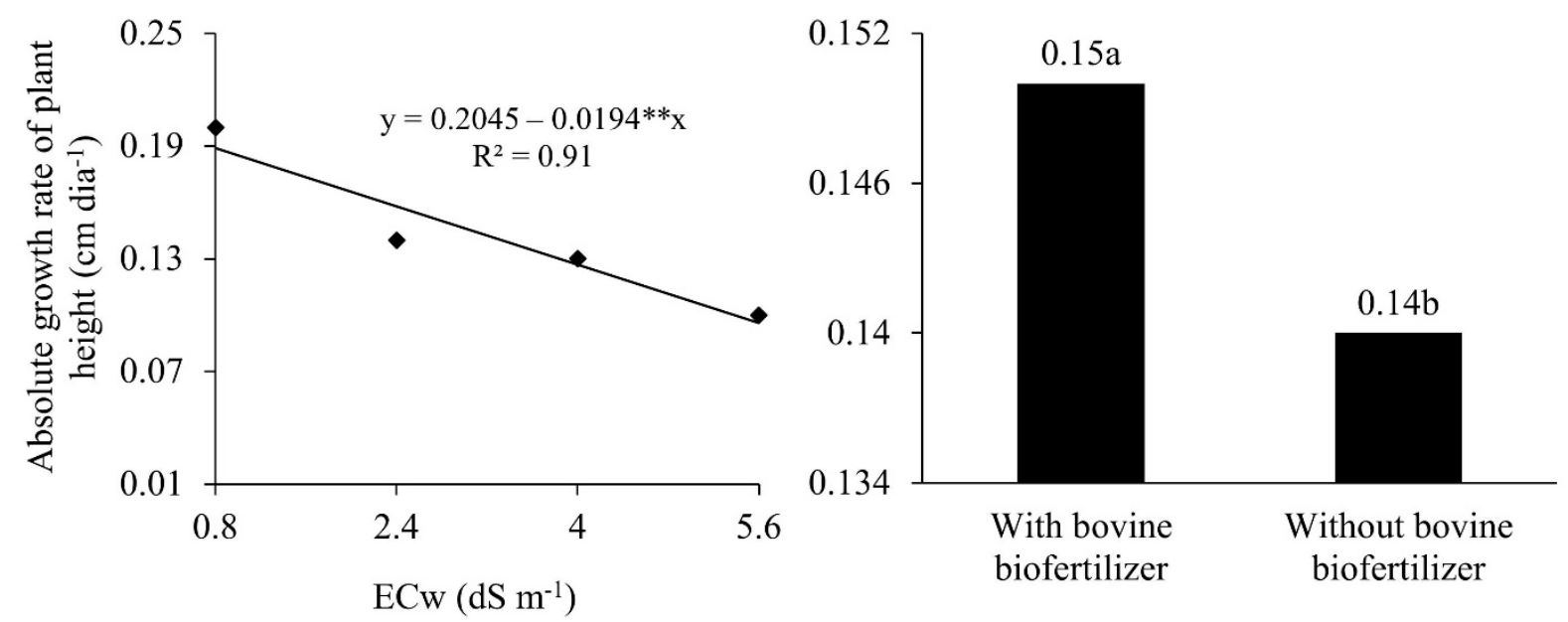

Figure 4. Absolute growth rate of plant height of eggplant plants under the ECw effect associated with the presence and absence of bovine biofertilizer.

Mesquita et al. (2012), observed that the absolute growth rate of plant height of the yellow passion fruit plant decreased for all of the treatments with increasing irrigation water salinity with an average value of $1.43 \mathrm{~cm} \mathrm{day}^{-1}$, however, the same authors verified that the application of biofertilizer provided the best results $\left(2.87 \mathrm{~cm} \mathrm{day}^{-1}\right)$ corresponding to the lowest water estimated salinity of $0.5 \mathrm{dS} \mathrm{m} \mathrm{m}^{-1}$.
The ECw negatively affected the relative growth rate of plant height of eggplant plants and, according to the regression equation (Figure 5), where the data were best adjusted to the linear model, shows a decrease in RGRph of $80 \%$ for a unit increase of ECw, representing a reduction of $0.0008 \mathrm{~cm}^{-1}$ day $^{-1}$ in the RGRph of the plants irrigated with ECW of $5.6 \mathrm{dS} \mathrm{m}^{-1}$ when compared to those irrigated with water of $0.8 \mathrm{dS} \mathrm{m}^{-1}$. 


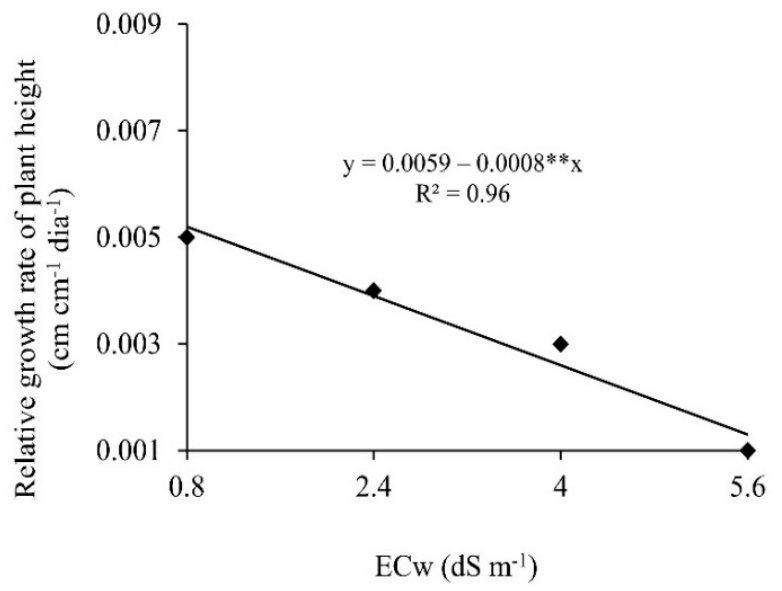

Figure 5. Relative growth rate of plant height of eggplant plants under the ECw effect.

Mesquita et al. (2012) verified that the relative growth of plant height was reduced as the ECw increased at 25 days after the emergence, with extreme values of 0.08 and $0.083 \mathrm{~cm}$ day $^{-1}$ with ECw of 0.5 and 1.0 $\mathrm{dS} \mathrm{m} \mathrm{m}^{-1}$, respectively. One of the parameters to evaluate the effects of saline stress as well as the capacity of the plant to overcome the salinity is by the growth rate and the biomass production, since the processes of plant growth are particularly sensitive to the effect of the salts (MORAIS Et al., 2011). Reductions in leaf area relative growth rates are mainly due to the deleterious effect of salts excess on plant metabolism (SANTOS et al., 2013).

The increase of ECw promoted a reduction in the relative growth rate of stem diameter, presenting a linear decrease, according to the regression equation (Figure 6), a reduction of $0.0014 \mathrm{~mm}$ $\mathrm{mm}^{-1}$ day ${ }^{-1}$ for each increased unit of ECw, which implies that, when the plants were irrigated with ECw of $5.6 \mathrm{dS} \mathrm{m}^{-1}$, there was a decline in the RGRsd of $0.0013 \mathrm{~mm} \mathrm{~mm}^{-1}$ day $^{-1}$ when compared to the plants irrigated with ECw of 0.8 $\mathrm{dS} \mathrm{m}^{-1}$.
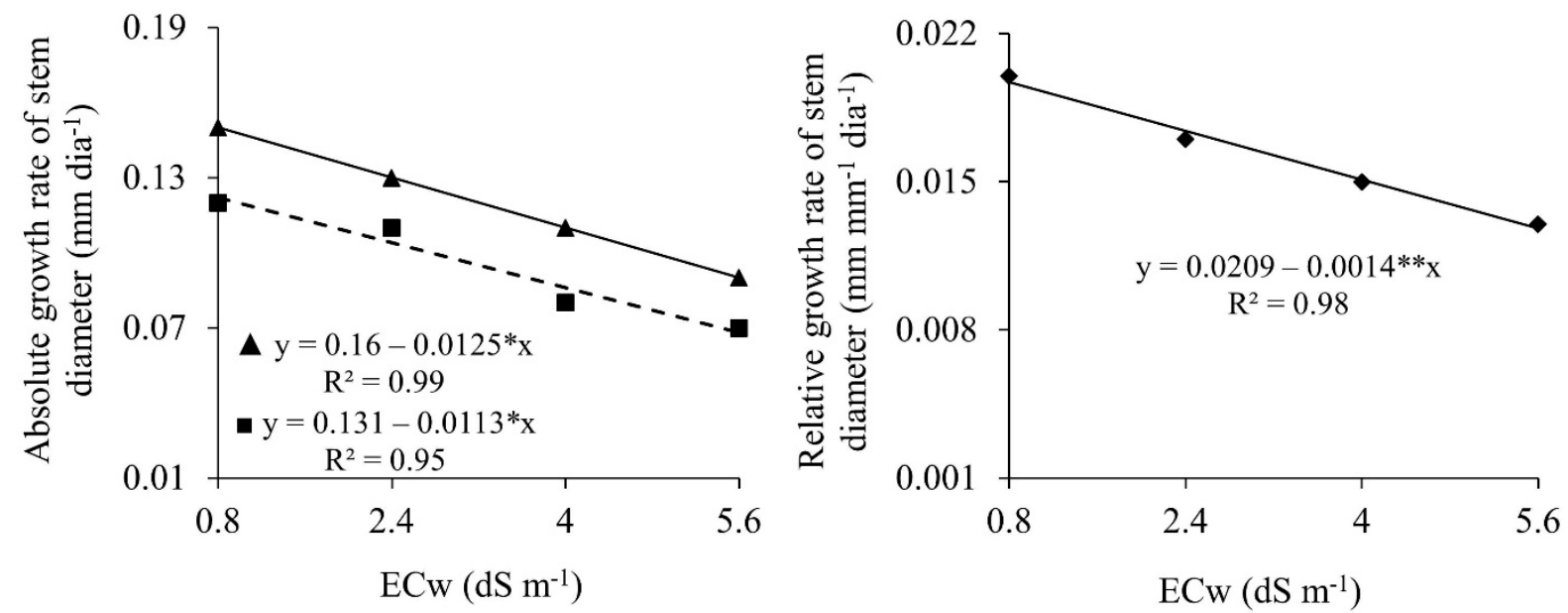

Figure 6. Absolute and relative growth rate of stem diameter of eggplant plants under the effect of the electrical conductivities of irrigation water associated with the presence $(\boldsymbol{\Delta})$ and absence $(\boldsymbol{\bullet})$ of bovine biofertilizer.

Mesquita et al. (2012) found that the absolute growth rate of yellow passion fruit reached mean values of 0.034 and 0.031 cm.day $^{-1}$ in the soil with and without biofertilizer, respectively, and the relative growth rate of stem diameter reached a mean value of $0.025 \mathrm{~cm}^{-1} \mathrm{day}^{-1}$. Sousa et al. (2013b), also verified that the absolute growth rate of stem diameter of yellow passion fruit (Passiflora edullis Sims.) had a reduction with the increase of the salinity levels of the irrigation water, regardless of the absence or presence of the organic input. However, observed that the declines were lower in the treatments with the organic input.

Based on the regression equation of the absolute growth rate of leaf area (Figure 7), it was found that there was a linear decrease as the level of salinity of the water increased of $55.43 \%$ per unit increase of ECw, where the plants irrigated with ECw of $5.6 \mathrm{dS} \mathrm{m}^{-1}$ had the AGRla reduced by $0.51 \mathrm{~cm}^{2}$ day ${ }^{-1}$ when compared to those irrigated with ECw of $0.8 \mathrm{dS}$ $\mathrm{m}^{-1}$.

It was found that the biofertilizer provided positive results with its application to 
the absolute growth rate of leaf area, indicating that, the plants that received the application of the biofeertilizer presented a growth rate of 0.71 $\mathrm{cm}^{2}$ day $^{-1}$, whereas the plants that did not receive the treatment had a growth rate of 0.68 $\mathrm{cm}^{2}$ day $^{-1}$ (Figure 7).
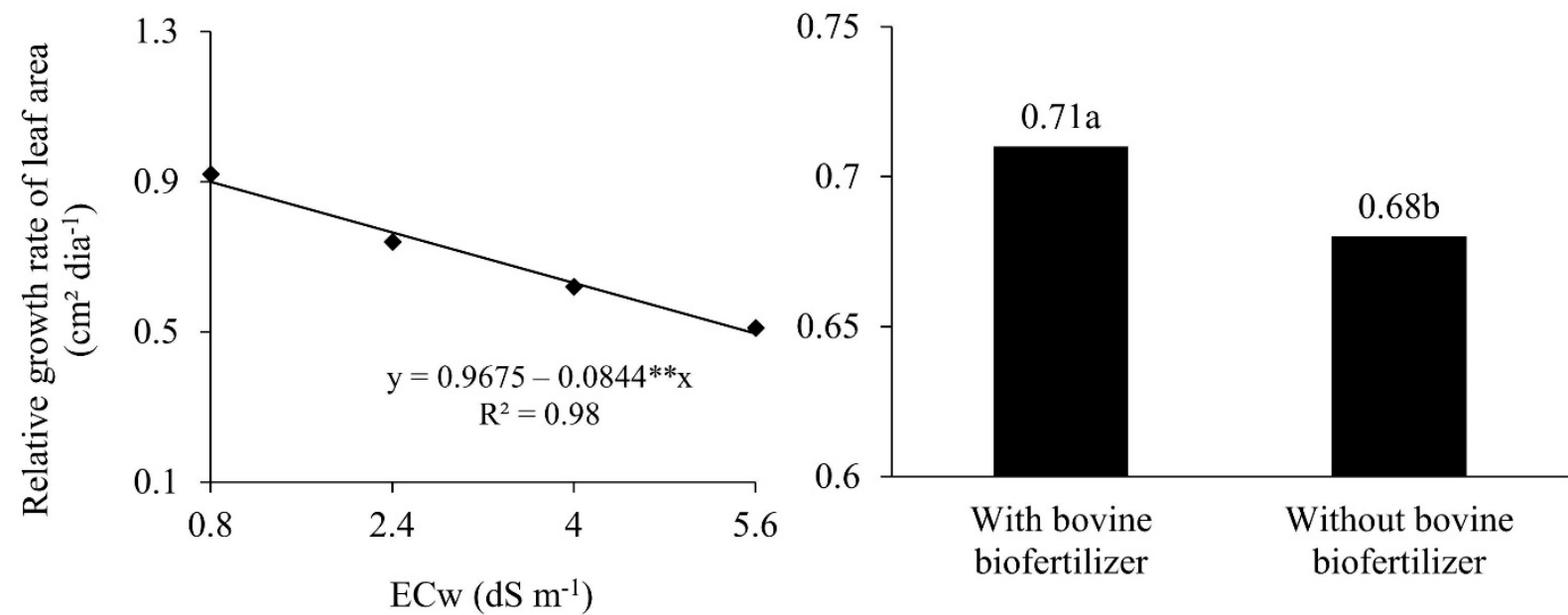

Figure 7. Absolute growth rate of leaf area of eggplant plants under ECw effect associated with the presence and absence of bovine biofertilizer. Means followed by the same letter do not differ statistically by the Tukey test at $5 \%$ of probability.

The relative growth rate of leaf area was significantly influenced by the ECw increase and, according to the regression equation (Figure 8), there was a decrease of $38.23 \%$ for each increase unit of the ECw, showing a reduction of $0.0013 \mathrm{~cm}^{2} \mathrm{~cm}^{2}$ Day $^{-1}$ in the RGR when comparing the plants irrigated with ECw water of $5.6 \mathrm{dS} \mathrm{m}^{-1}$ to those irrigated with water of 0.8 $\mathrm{dS} \mathrm{m}^{-1}$.

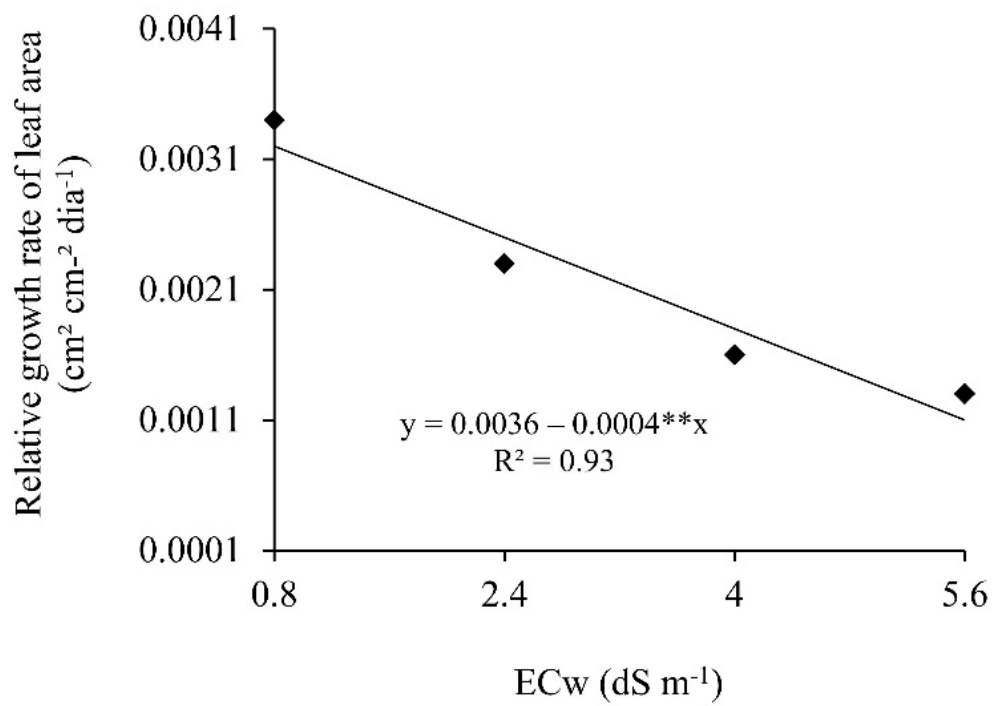

Figure 8. Relative growth rate of leaf area of eggplant plant under ECw effect.

It is observed that the root dry matter, stem dry matter, leaf dry matter and total dry matter (Figure 9) were significantly influenced by the interaction between ECw $\mathrm{x}$ application of bovine biofertilizer, all better adjusted to the linear descending model; Under the conditions of low salinity $\left(0.8 \mathrm{dS} \mathrm{\textrm {m } ^ { - 1 }}\right)$ and with the application of biofertilizer, the eggplant plants had maximum values of 4.79 ; 7.58; 14.1 ; and $26.5 \mathrm{~g}$ for root dry matter, stem dry matter, leaf dry and total dry matter, respectively. 

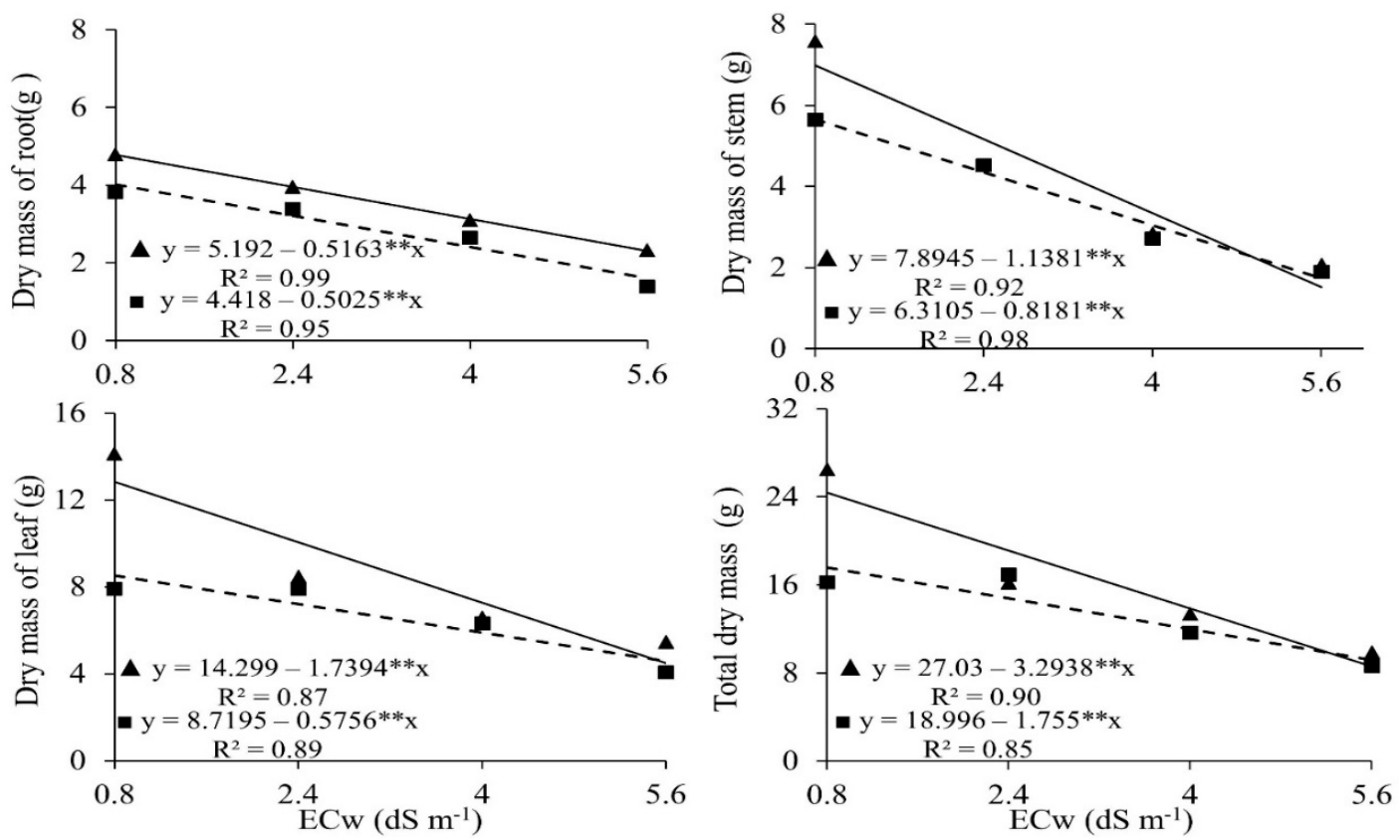

Figure 9. Dry matter of roots, stem, root and total dry matter of eggplant plants irrigated under ECw effect associated with presence $(\boldsymbol{\Delta})$ and absence $(\boldsymbol{\square})$ of bovine biofertilizer.

Silva et al. (2013) also found that the dry matter of the eggplant root was affected by the salts in the irrigation water, observing a quadratic response model, obtaining mean of $78.57 \mathrm{~g}$ and, as ECw increased, there was an expressive increase until the ECw of $3 \mathrm{dS} \mathrm{m}^{-1}$, later reduction in dry mass of the root. The same authors found a significant reduction in the accumulation of dry matter of leaves in response to the salinity, but only observed a significant effect for salinity above $3.3 \mathrm{dS} \mathrm{m} \mathrm{m}^{-1}$. Bosco et al. (2009) studied the eggplant cultivar Florida Market, and verified that the data were adjusted to the quadratic and linear response models, with reductions in the dry matter of the root as the salinity level in the nutrient solution was increased, mainly in the treatments in which the ECw of the nutrient solution was higher than $4.08 \mathrm{dS} \mathrm{m}^{-1}$.

Oliveira et al. (2011), working with the eggplant cv. Preta Comprida and saline water with levels varying from 0.5 to $4.5 \mathrm{dS} \mathrm{m} \mathrm{m}^{-1}$, found relative losses of $49.2 \%$ for leaf dry matter. The lower production of dry matter of the plants occurs due to the salinity effects, reducing the water availability to the plants due to the decrease of the total potential of the water in the soil, and as a consequence, the plants has to spend more energy for water absorption (LEONARDO et al., 2007).
It is observed in Figure 10 that the increase of ECw promoted significant effects on the Dickson Quality Index (DQI) and, it is verified a reduction as the ECW is increased.

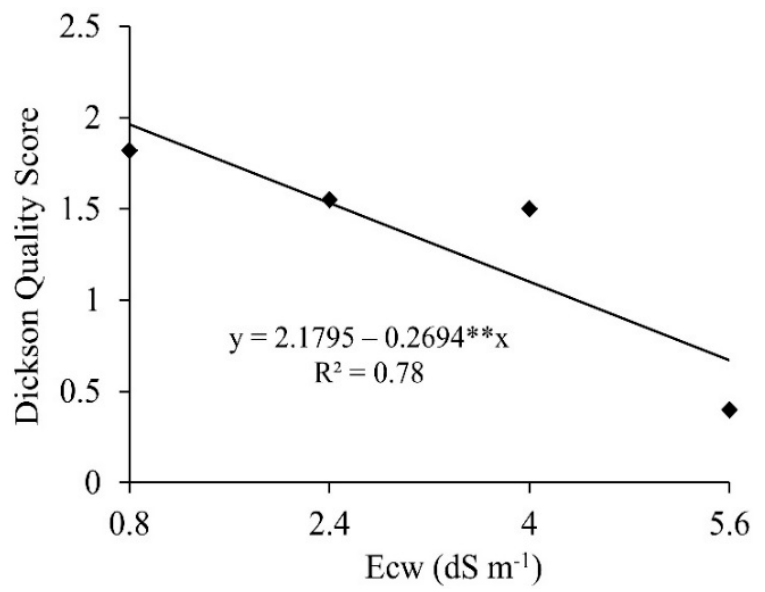

Figure 10. Dickson Quality Index of eggplants plants under different ECw effects.

The biofertilizer possibly attenuated the negative effects of the salinity on the plants since the organic input stimulates the proliferation of microorganisms and solubilizers of essential nutrients in the soil, increasing their availability to the plants. The bovine biofertilizer has a positive action, acting in the improvement of the soil quality in terms of aeration, besides the supplying of nutrients and organic matter to the plants. In addition, the 
biofertilizer has many beneficial substances, among them humic substances, which promote the reduction of the osmotic potential of the soil solution, stimulating the absorption of water and nutrients by the plants in saline environments (SOUSA et al., 2013a).

\section{CONCLUSIONS}

The increase in the salinity of the irrigation water negatively affects the growth and dry matter production of eggplant plants (Solanum melongena L.); the application of bovine biofertilizer provides positive results in eggplant, attenuating the negative effects of saline stress during the growth phase and in the dry matter production of the plant.

\section{REFERENCES}

AYDIN, A.; KANT, C.; TURAN, M. Humic acid application alleviate salinity stress of bean (Phaseolus vulgaris L.) plants decreasing membrane leakage. African Journal of Agricultural Research, v. 7, n. 7, p. 10731086, 2012.

BOSCO, M. R. D. O.; OLIVEIRA, A. B.; HERNANDEZ, F. F. F.; LACERDA, C. F. Efeito do $\mathrm{NaCl}$ sobre o crescimento, fotossíntese e relações hídricas de plantas de berinjela. Ceres, v. 56, n. 3, p. 296-302, 2015.

BOSCO, M. R. O.; OLIVEIRA, A. B.; HERNANDEZ, F. F. F.; LACERDA, C. F. Influência do estresse salino na composição mineral da berinjela. Revista Ciência Agronômica, v. 40, n. 2, p. 157-164, 2009.

CAMPOS, V. B.; CAVALCANTE, L. F. Salinidade da água e biofertilizante bovino: efeito sobre a biometria do pimentão. Holos, v. 25, n. 1, p. 10-20, 2009.

COSTA, E.; DURANTE, L. G. Y.; NAGEL, P. L.; FERREIRA, C. R.; SANTOS, A. Qualidade de mudas de berinjela submetida a diferentes métodos de produção. Revista Ciência Agronômica, v. 42, n. 4, p. 1017-1025, 2011.

FERREIRA, D. F. Sisvar: A computer statistical analysis system. Ciência e Agrotecnologia, v. 35, n. 7, p. 1039-1042, 2011.

LEONARDO, M.; BROETTO, F.; VILLASBÔAS, R. L.; ALMEIDA, R. S.; MARCHESE, J. A. Produção de frutos de pimentão em diferentes concentrações salinas. Irriga, v. 12, n. 1, p. 73-77, 2007.

MAHMOUD, A. A.; MOHAMED, H. F. Impact of biofertilizers application on improving wheat (Triticum aestivum L.) resistance to salinity. Research Journal of Agriculture and Biological Sciences, v. 4, n. 5, p. 520-528, 2008.

MEDEIROS, R. F.; CAVALCANTE, L. F.; MESQUITA, F. O.; RODRIGUES, R. M.; SOUSA, G. G.; DINIZ, A. A. Crescimento inicial do tomateiro-cereja sob irrigação com águas salinas em solo com biofertilizantes bovino. Revista Brasileira de Engenharia Agrícola e Ambiental, v. 15, n. 5, p. 505-511, 2011.

MESQUITA, F. O.; REBEQUI, A. M.; CAVALCANTE, L. F.; SOUTO, A. G. D. L. Crescimento absoluto e relativo de mudas de maracujazeiro sob biofertilizante e águas salinas. Revista de Ciências Agrárias, v. 35, n. 1, p. 222-239, 2012.

MESQUITA, F. O.; CAVALCANTE, L. F.; PEREIRA, W. E.; LIMA NETO, A. J.; NUNES, J. C. 2012. Produção de mudas de maracujazeiro amarelo submetidas à salinidade em solo como biofertilizante bovino. Ciencia del suelo, v. 30, n. 1, p. 31-41, 2012.

MORAIS, F. A.; GURGEL, M. T.; OLIVEIRA, F. H. H.; MOTA, A. F. Influência da irrigação com água salina na cultura do girassol. Revista Ciência Agronômica, v. 42, n. 2, p. 327-336, 2011. 
MOURA, D. C. M., CARVALHO, J. A. Efeitos de diferentes lâminas e teores de sais na água de irrigação sobre o desenvolvimento e produção da berinjela. Irriga, v. 19, n. 1, p. 35-45, 2014.

OLIVEIRA, F. D. A.; CAMPOS, D. S.; OLIVEIRA, F. R.; OLIVEIRA, M. K.; MEDEIROS, J. F.; MELO, T. K. Desenvolvimento e concentração de nitrogênio, fósforo e potássio no tecido foliar da berinjela em função da salinidade. Revista Brasileira de Ciências Agrárias, v. 6, n. 1, p. 37-45, 2011.

RHOADES, J. D.; KANDIAH, A.; MASHALI, A. M. Uso de águas salinas para produção agrícola. UFPB: Campina Grande, $\mathrm{PB}$, Brasil, 2000. 117p. (Estudos FAO Irrigação e drenagem, 48).

RICHARDS, L.A. Diagnosis and improvement of saline and alkali soils. Washington: US Department of Agriculture, 1954. 160p. (USDA Agricultural Handbook, $60)$.

SANTOS, J. B.; SANTOS, D. B.; AZEVEDO, C. A.; REBEQUI, A. M.; CAVALCANTE, L. F.; CAVALCANTE, Í. H. Comportamento morfofisiológico da mamoneira BRS Energia submetida à irrigação com água salina. Revista Brasileira de Engenharia Agricola e Ambiental, v. 17, n. 2, p. 145-153, 2013.

SILVA, E. M.; SOUZA C. J. G. L.; DUARTE, S. N.; BARBOSA, F. S.; MASCHIO, R. Níveis de salinidade e manejo da fertirrigação sobre características da berinjela cultivada em ambiente protegido. Revista Ciência Agronômica, v. 44, n. 1, p. 150-158, 2013.

SILVA, J. A.; OLIVEIRA, A. P.; ALVES, G. S.; CAVALCANTE, L. F.; OLIVEIRA, A. N. P.; MARIA, A. M. ARAÚJO. Rendimento do inhame adubado com esterco bovino e biofertilizante no solo e na folha. Revista Brasileira de Engenharia Agrícola e Ambiental, v.16, n. 3, p. 253-257, 2012.

SOUSA, G. G.; VIANA, T. V. A.; BRAGA, E. S.; AZEVEDO, B. M.; MARINHO, A. B.; BORGES, F. R. M. Fertirrigação com biofertilizante bovino: efeitos no crescimento, trocas gasosas e na produtividade do pinhãomanso. Revista Brasileira de Ciências Agrárias, v. 8, n. 3, p. 503-509, 2013 a.

SOUSA, G. B.; CAVALCANTE, L. F.; CAVALCANTE, I. H. L.; BEKMANNCAVALCANTE, M. Z.; NASCIMENTO, J. A. Salinidade do substrato contendo biofertilizante para formação de mudas de maracujazeiro amarelo irrigado com água salina. Revista Caatinga, v. 21, n. 2, p. 172-180, 2013b.

ÜNLÜKARA, A.; KURUN, A.; KESMEZ, G. D.; YURTSEVEN, E.; SUAREZ, D. L. Effects of salinity on eggplant (Solanum melongena L.) growth and evapotranspiration. Irrigation and Drainage, v. 59, n. 2, p. 203-214, 2010. 